\title{
E-commerce adoption in Malaysian Small and Medium Enterprises Practitioner Firms: A revisit on Rogers' model
}

\author{
MEHDI M. POORANGI ${ }^{1}$, EDWARD W.S. KHIN ${ }^{1}$, SHOHREH NIKOONEJAD ${ }^{2}$ and ARASH KARDEVANI ${ }^{2}$ \\ ${ }^{1}$ Faculty of Business and Accountancy, University of Malaya, 50603 Kuala Lumpur, Malaysia \\ ${ }^{2}$ Graduate School of Management, Multimedia University, 63100 Cyverjaya, Malaysia \\ Manuscript received on May 28, 2012; accepted for publication on April 15, 2013
}

\begin{abstract}
The current climate of business necessitates competitions that are often tough and unpredictable. All organizations, regardless their size and scope of operation, are facing severe competitive challenges. In order to cope with this phenomenon, managers are turning to e-commerce in their respective organizations. The present study hinges upon exploring and explaining the different dimensions of the adoption of e-commerce among Small and medium enterprises, based on the Five Factors of Diffusion of Innovation Model derived by Rogers. In this study, however, we employed the survey methods. A questionnaire was distributed to 1,200 managers and employees in the manufacturing, service and agricultural sectors by email; with a response rate of $10 \%$. The results gleamed from this study posits that relative advantage is influential vis-à-vis e-commerce adoption. Trialability and Observability factors affect the level of confidence of management, which in turn, influences e-commerce adoption. Meanwhile, the existing culture of a company affects the resistance of employees, which in turn negatively effects the e-commerce adoption, while complexity does not significantly influence the e-commerce adoption.
\end{abstract}

Key words: e-commerce adoption, SMEs, Rogers Model, diffusion of innovation, e-business.

\section{INTRODUCTION}

The adoption of Information Technology (IT) is extremely important to the development of an economic system (Nasco et al. 2008, Kendall et al. 2006). Although IT adoption has actually been studied by academics and practitioners for over a decade, with several theories attempting to illustrate IT adoption in various domains, there are still salient factors that are yet to be explored in detail. First, only a small number of researchers focusing upon technology adoption are working on the adoption itself, or applying electronic

Correspondence to: Mehdi Mohammadi Poorangi

E-mail: poorangi@siswa.um.edu.my commerce (e-commerce) in small and medium enterprises (Nasco et al. 2008). It is undeniable that the contribution of SMEs towards national economies is significant, especially in the context of the rapid growth that is currently being witnessed in developing countries around the globe (Poorangi and Khin 2013). SMEs differ in their adoption of IT when compared to their larger counterparts (Lee et al. 2002). For one, SMEs regard technology as difficult to implement due to their limited resources (Street and Meinster 2004), which necessitates the study of whether or not the adoption of IT in large organizations are analogous with the ones adopted by SMEs. Second, there is also a need to verify the 
validity of current theories in different contexts. The target of IT adoption study is concentrated in countries such as USA, Canada, and the UK, simply because most of the research and academic institutions or centres are located in those countries. The issue gets even more challenging due to the fact that the transition of IT adoption into developing countries is not considered smooth (Al Sukkar and Hasan 2005). The third factor is the fact that most studies related to IT adoption in SMEs in the context of developing countries are mostly descriptive, and lacks a powerful theoretical groundwork (Stylianou et al. 2003, Wresch 2003). This research aims to mitigate these shortcomings by applying the diffusion theory to examine the major factors influencing the adoption of e-commerce among SMEs in a developing country, primarily Malaysia. The outcome of the project might also be relevant to other developing countries in the region, as it might help uncover options in promoting the adoption of e-commerce that might boost their economic growth (Nasco et al. 2008).

Due to the fact that the current economical climate is becoming ever more competitive. Organizations, regardless their size and scope of operations have to maintain their edge by becoming strategically powerful in order to survive. Malaysia's economy is growing at a healthy rate, and due to this growth, the Malaysian government is allocating funds for SMEs. The SMEs are also obliged to observe the crucial elements of economic and industrial developments in their surroundings, and they must also be more innovative and flexible vis-à-vis superior technology adaptation and implementation. MacGregor and Vrazalic (2007) posit that e-commerce is an instrument for the exchange of business information, products and services, which might affect a company's supply chain. E-commerce is not only restricted to buying and selling on the internet, but encompasses product exchange, services and information, or knowledge by using a personal computer or laptop via the Internet, extranet or intranet. E-commerce includes online services to a customer, improved co-operation with business associates, as well as enhancing exchange of business documents within an organization via the Internet or individual networks (Al-Somali et al. 2011, Hunaiti et al. 2009).

The present study hinges upon the exploration and explanation of the different dimensions of e-commerce adoption among SMEs based on the Five Factors of Diffusion of Innovation Model derived by Rogers by illustrating the influences of this model's dimensions on the adoption of e-commerce amongst Malaysian SMEs.

Based on Rogers' Diffusion of Innovation Theory, there are five factors influencing the rate of adoption. Four out of five factors positively influences the rate of adoption, which are: Relative Advantage (the degree to which an innovation is realized or perceived as better than the idea it supersedes); Compatibility (the degree to which an innovation is perceived as being compatible with existing values, past experiences, and the needs of potential adopters); Trialability (the degree to which the innovation may be tested or piloted and modified) and Observability (the degree to which the results of the innovation are visible to others). On the other hand, Complexity (the degree to which an innovation is perceived as difficult to understand and use) negatively affects the rate of adoption.

\section{ROGER'S THEORY}

Roger's Diffusion of Innovations Theory is "the process by which an innovation is communicated through certain channels over time among the members of a social society". It is divided into two categories: The first category suggests innovation (company), while the second category requests the adoption of innovation (customer). Based on this definition of the theory, five factors that affect the rate of adoption are the relative advantage, compatibility, Trialability, Observability, and complexity. 


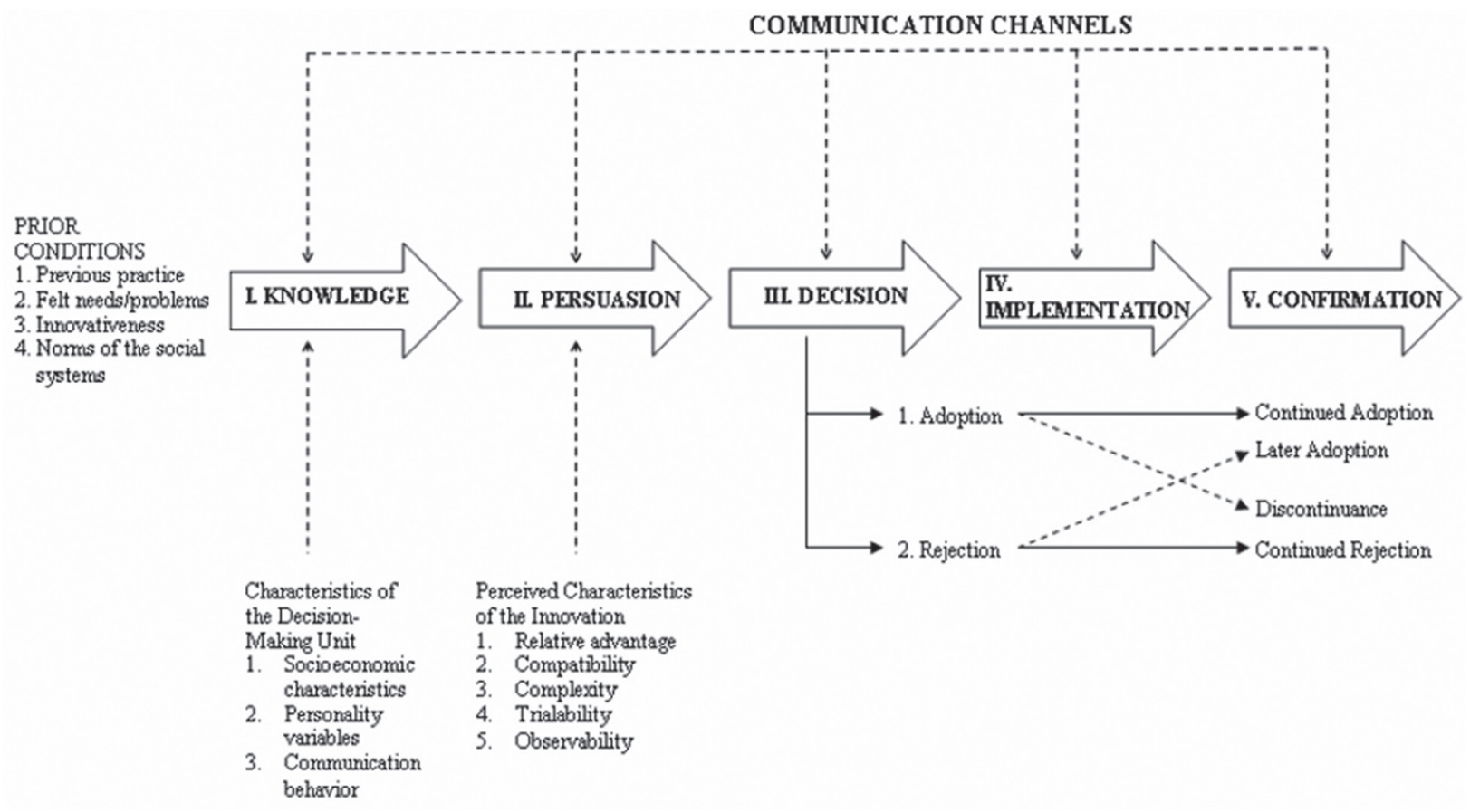

Figure 1 - Roger (1995:163), "Innovation - Decision Process".

\section{E-COMMERCE ADOPTION AMONG SMES}

As SMEs are important for the economy of the country, it is vital to persuade e-commerce adoption in SMEs as the source of competitive advantages. Companies use e-commerce for a variety of reasons, as stated by Karakaya and Shea (2008). Some companies believe that e-business creates new options for their customers, instigates fast new product delivery and services, as well as lowering costs. Moreover, some other companies also adopt e-commerce in order to increase sales, reduce costs, provide better customer service, gather market information, improve productivity, as well as discover and retain new customers.

The study conducted by Poon and Swatman (1997) showed that e-commerce could positively influence SMEs' productivity, which in turn enables them to compete against larger companies. Simultaneously, the adoption of e-commerce is a cost-effective tool for the SMEs to market and launch new products, improves client communications, as well as enhancing the collection of marketing knowledge and information (Hunaiti et al. 2009). Moreover, the adoption of e-commerce within SMEs gives way to unique opportunities for businesses to engage international firms, which they are unable to do in the past. The adoption of e-commerce increases the productivity within SMEs via the reformation of work action and techniques; where it improves customer service and record keeping. Research conducted in Thailand also confirm that e-commerce is intended to (1) improve electronic "monetary services", (2) facilitate and support e-commerce activities, (3) build up e-commerce laws and rules, (4) connect and make use of the information among the government, businesses and service sections, as well as (5) recover the management of backoffice systems, service systems and transportation systems for the industrialized processes and services (MacGregor and Vrazalic 2007).

\section{DIFFUSION MODEL AND E-COMMERCE ADOPTION IN SMES}

Jon et al. (2001) partly illustrated the use of the diffusion model on the e-commerce adoption in 
SMEs. However, the diffusion of innovation model derived by Roger, as well as the study of e-commerce adoption in Malaysian companies and SMEs is still in its infancy. Based on Tan and Eze (2008), the theory of Roger's diffusion of innovation in 1995 defined the term relative advantage as the degree to which "an innovation is perceived as being better than the idea it supersedes". Relative advantage is an important item in the adoption of innovations, and they are positively related to the adoption of e-commerce (Grandon and Pearson 2004). Previous works pointed out that e-commerce is a solution that would steer firms to a better financial performance and increased competitiveness and efficiency in operations. Despite these perceived improvements, managers of SMEs are still sceptical towards the adoption of SMEs due to their respective resource and technological limitations (Migiro 2006, Daniel and Grimshaw 2002). Based on surveys in several countries such as Kenya, SMEs have limited access to the Internet, market, finance, and the latest technologies (Maswera et al. 2008). These limitations are perceived to have caused the SMEs in Kenya to suffer low productivity, lower growth rate towards a global position, limited knowledge concerning knowledge and information technology expertise, and limited market share (Maswera et al. 2008).

Migiro (2006) explains that the adoption of e-commerce by SMEs enables them to compete in the global market, and to improve their efficiency, and also closes the relationship gap between customers and suppliers. Referring to the theory of Rogers (1995) and Migiro (2006), it can be assumed that the motivations for the adoption of e-commerce in SMEs are: 1.Interaction with customers, 2.Taking orders online, 3. Increase sales, 4. New customers and market penetration, 5. Marketing strategies, 6 . Improve quality of their information, 7. Increase internal efficiency and improved competitiveness. Furthermore, a survey related to the adoption of e-commerce with SMEs in Australia showed that the benefits of SMEs are (1) cost and competitiveness, (2) sales and marketing, as well as (3) administration and partnerships. The adoption of e-commerce also reduces production costs and lead times, increases internal efficiency, and improves the quality of information and competitiveness. In addition, the adoption of e-commerce also reduces administrative cost and improves relationships between business partners in the context of sales and marketing. It also reduces stock levels, increases sales and internal efficiency, and grants access to new customers.

One study, which applied Rogers' theory in Australia by Chong and Pervan (2007), shows that SMEs uses e-commerce and relative advantage, which has a strong relationship with the adoption of e-commerce among SMEs. On the other hand, research done in the South East Asian region by Jon et al. (2001) denotes that relative advantage is the only factor strongly influencing the adoption of e-commerce. This is incumbent upon the perceived relative advantage of the willingness of the SMEs to adopt e-commerce. Based on a study by Azam and Quaddus (2009a), the economy in Bangladesh is growing, due the development and the attention paid by the government to the SMEs. He added the fact that the improvement of SMEs' productivity performance is also related to the adoption of e-commerce. However, based on further research in Bangladesh by Md. Azam and Quadddus (2009b), relative advantage seems to be the best prediction for innovation, and that perceived compatibility is also an important factor influencing the acceptance of e-commerce among SMEs in Bangladesh.

The result of a research conducted by Chen (2004) in Taiwan shows that relative advantage, complexity, observability and government policies are the parameters that mainly influence the acceptance of electronic commerce. It also shows that SMEs weigh in these factors when they decide to adopt e-commerce, with cost and benefit also related to relative advantage. Based on another study by Grandon and Pearson (2004), relative 
advantage is an important predictor for the adoption of e-commerce by SMEs in the United States. This research explains the fact that in the USA, the use of the Internet has created an environment that is ripe for the adoption of e-commerce. Based on research by Husnayati et al. (2008), in which Rogers' theory were also applied in their research, all the five factors, especially relative advantage, has a strong relationship with the adoption of e-commerce in Malaysian manufacturing SMEs. Other studies conducted by Oliveira and Martins (2010) stated that organizations that use e-business strategi3es and applications will achieve and enjoy improvements in efficiency, increases in sales, increases and improvements in customer relationships, and the ability to expand to new markets and increased turnover. At the same time, SMEs also have an important role in the national and regional economic performance.

Based on the theory of Roger's diffusion of innovation and the adoption of e-commerce in SMEs, the research questions that are being posed are:

1. In what extent the relative advantages of innovation can increase the speed of e-commerce adoption process in SMEs?

2. Do trialability and observablity in the adoption of e-commerce can increase the confidence level of managers to continue the adoption process?

3. Does the compatibility of e-commerce adoption processes through its effect on firms existing culture can decrease the degree of employee resistance against e-commerce adoption?

4. Does complexity reduce the rate of adoption of e-commerce among Malaysian SMEs?

\section{CONCEPTUAL MODEL AND HyPothesis}

After completing the literature review survey, the next stage is the development of theoretical framework, along with the discussion of the relationships among the variables. The primary goal of this study is to investigate the influences of the factors of Rogers's theory on the adoption of e-commerce in SMEs.

In this study, five factors of Rogers's theory (relative advantage, compatibility, complexity, Trialability, Observability) are selected, and their influences on the adoption of e-commerce are duly investigated. Rogers in 1962 defined Relative Advantage as 'the degree to which an innovation is realize or perceive as better than the idea it supersedes'; and compatibility as 'it is the degree to which an innovation is perceived as being compatible with existing values, past experiences, and the needs of potential adopters'; Trialability as 'the degree to which the innovation may be tested or piloted and modified'; and Observability 'the degree to which the results of the innovation are visible to others', Complexity 'the degree to which an innovation is perceived as difficult to understand and use', which may be negatively correlated with the rate of adoption. Based on previous research, the adoption of e-commerce enhances the levels of innovation within SMEs, and is also influential during the process of making the decision of whether or not the management is willing to adopt other IT related technologies. Moreover, these technologies are very influential vis-à-vis a firm's current culture, and is capable of shifting a business paradigm from a traditional to a more modern era, which might represent a daunting aspect for certain managers or employees. This necessitates some form of training for these category of professionals, which will enable them to gain knowledge and information regarding new technologies, and cope with new settings. These actions can weaken employee's resistance, and simultaneously impress the management team enough to encourage them to maintain the effort towards the adoption process. In accordance with this statement, a conceptual model based on the theory of Roger's model (diffusion of innovation) has been proposed. 


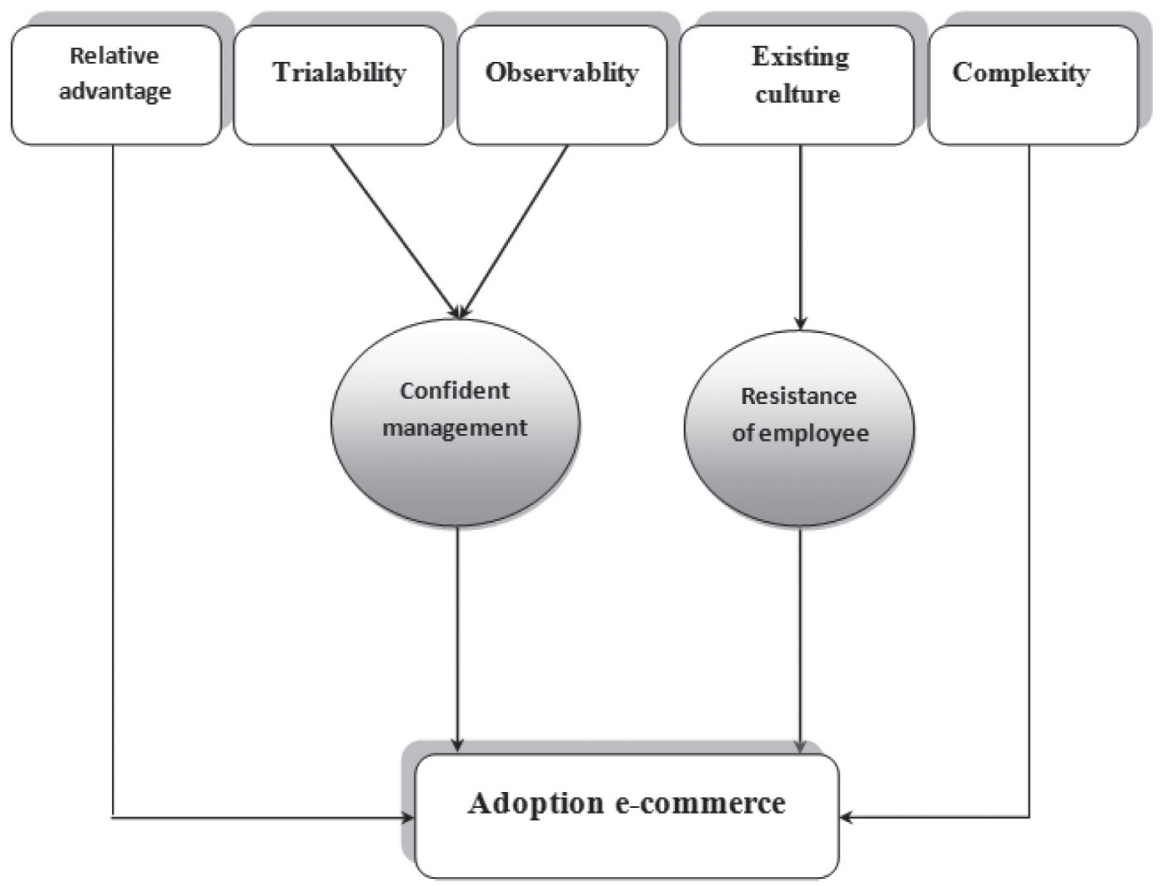

Figure 2 - Conceptual framework.

Based on study framework following hypothesises has been proposed:

H1: Higher rate of relative advantage of innovation in SMEs will increase the speed of e-commerce adoption process.

H2a: Higher rate of Trialability in e-commerce adoption will increase the degree of managers' confidence to continue the adoption process.

H2b: Higher rate of Observablity in e-commerce adoption will increase the degree of managers' confidence to continue the adoption process.

H2c: Confidence of management will influence the adoption of e-commerce continuation

H3a: Based on compatibility model, existing culture of e-commerce adoption in SMEs can decrease the degree of employee resistance against e-commerce adoption.

H3b: Based on the degree of resistance, employee resistance can influence the e-commerce adoption.
H4: Complexity negatively related with adoption of e-commerce.

\section{MATERIALS AND METHODS}

In order to realize a comprehensive result, this study uses both primary and secondary data sources. Secondary data are derived from publications and textbooks, while the primary data in this study involved a simple survey questionnaire that were distributed among executives of 1,200 SMEs in Malaysia for them to answer research based questions that addresses the gaps in the literature. The response rate to this questionnaire was almost $10 \%$. The Cronbach's Alpha test was utilized in order to test the reliability (the degree to which an instrument measures the same way each time under the same condition with same subject) of the instrument. All of the measures have been adapted from the studies of Jon et al. (2001), Kendall et al. (2006) and Grandon and Pearson (2004), utilizing a 7 Likert scale. The reliability of all of the variables is illustrated in the reliability table below. 
Reliability Table

\begin{tabular}{|l|l|l|}
\hline Variables & $\begin{array}{l}\text { Cronbach's } \\
\text { Alpha }\end{array}$ & N of Items \\
\hline Relative Advantage & 0.891 & 4 \\
\hline Trialability & 0.772 & 3 \\
\hline Observablity & 0.942 & 4 \\
\hline Existing Culture & 0.853 & 8 \\
\hline Complexity & 0.778 & 2 \\
\hline E-commerce Adoption & 0.86 & 6 \\
\hline Confident Management & 0.809 & 3 \\
\hline Employee resistance & 0.748 & 3 \\
\hline
\end{tabular}

SAMPLING AND DATA COLLECTION PROCEDURE

Based on the Malaysian Bureau of Statistics (2012), 645,136 SMEs are active in three main economic sectors, namely services, agriculture, and manufacturing. These SMEs are categorized based on their respective sizes, which are micro, small, and medium sized enterprises. The largest sector is services, containing 474,706 SMEs, followed by manufacturing with 39,373, and agriculture with 34,188 SMEs, which are mostly distributed across three main provinces of Selangor, Kuala Lumpur and Johor, respectively.

Sekaran (2006) posited that for almost all statistical approaches, a sample size of 30-300 would result in a satisfactory analysis. For the purpose of this study, we chose 300 SMEs that are located in Selangor and Kuala Lumpur, due to limitations in having unrestricted access to all possible SME's. A number of executives, mainly CEOs and business developers, and also first-line managers of SMEs, were asked to participate in the survey, which resulted in a total sample size of 1,200 respondents, with the questionnaire being send to them via email. The data analysis in this research was conducted using Statistical Packages for Social Science (SPSS) software version (17.0), via the utilization of the ANOVA and Coefficiency functions.

\section{RESULTS}

In this section, the results of the study, based on the research questions, are discussed. The following tables show the summary model, one-way ANOVA, as well as the coefficiency tables for Trialability and Observability variables.

TABLE I

Summary Model for Trialability and Observability. Model summary

\begin{tabular}{|c|c|c|c|c|}
\hline Model & R & R Square & $\begin{array}{c}\text { Adjusted } \\
\text { R Square }\end{array}$ & $\begin{array}{c}\text { Std. Error of } \\
\text { the Estimate }\end{array}$ \\
\hline 1 & $0.759^{\mathrm{a}}$ & 0.576 & 0.569 & 2.16641 \\
\hline
\end{tabular}

a. Predictors: (Constant), Observablity, Trialability.

The probability of the F-statistic is 0.000 , which is less than 0.05 (significance level). Therefore, this model is significant.

TABLE II

Summary Model for Trialability and Observability.

ANOVA $^{\mathbf{b}}$
\begin{tabular}{|c|c|c|c|c|c|}
\hline Model & $\begin{array}{c}\text { Sum of } \\
\text { Squares }\end{array}$ & df & $\begin{array}{c}\text { Mean } \\
\text { Square }\end{array}$ & F & Sig. \\
\hline 1 Regression & 745.245 & 2 & 372.622 & 79.394 & $0.000^{\mathrm{a}}$ \\
Residual & 549.122 & 117 & 4.693 & & \\
Total & $1,294.367$ & & 119 & & \\
\hline
\end{tabular}

a. Predictors: (Constant), Observablity, Trialability; b. Dependent Variable: Confident.

While the adjusted R-square is $0.569,56.9$ percent of variations in dependent variable (Confidence of managers) can be explained by two independent variables, namely Trialability and Observablity.

\section{TABLE III}

Coefficiency between Trialability, Observability and Confident.

Coefficients $^{\text {a }}$\begin{tabular}{|c|c|c|c|c|c|}
\hline $\begin{array}{c}\text { Model } \\
\text { Unstandardized } \\
\text { Coefficients }\end{array}$ & $\begin{array}{c}\text { Standardized } \\
\text { Coefficients }\end{array}$ & \multicolumn{4}{|l|}{} \\
\hline B & Std. Error & Beta & t & Sig & \\
1 (Constant) & 2.606 & 0.958 & & 2.721 & 0.007 \\
Trialability & 0.539 & 0.104 & 0.494 & 5.170 & 0.000 \\
Observablity & 0.218 & 0.068 & 0.309 & 3.233 & 0.002 \\
\hline
\end{tabular}

a. Dependent Variable: Confident. 
Based upon the regression model, the probability of the T-statistic for Trialability is 0.000 , which is less than 0.05 , and it can be concluded that there is a significant positive correlation between Trialability and the confidence of managers. Based on the regression model being taken as the probability of T-statistic for observability, it came out to 0.002 , which is less than 0 , and it can be can concluded that there is a significant positive relationship between observability and the confidence level of the managers.

The following tables show the summary model, one-way ANOVA, and coefficiency tables for the existing culture variable.

TABLE IV

Model Summary for Existing Culture.

Model Summary

\begin{tabular}{|c|c|c|c|c|}
\hline Model & R & R Square & $\begin{array}{c}\text { Adjusted R } \\
\text { Square }\end{array}$ & $\begin{array}{c}\text { Std. Error of } \\
\text { the Estimate }\end{array}$ \\
\hline 1 & $0.460^{\mathrm{a}}$ & 0.211 & 0.203 & 2.77721 \\
\hline
\end{tabular}

a. Predictors: (Constant), Existing Culture.

The probability of F-statistic is 0.000 , which is less than 0.05 (significance level). Therefore, this model is considered significant.

TABLE V

One Way ANOVA for Existing Culture and Resistance. ANOVA $^{\text {b }}$

\begin{tabular}{|c|c|c|c|c|c|}
\hline Model & $\begin{array}{c}\text { Sum of } \\
\text { Squares }\end{array}$ & df & $\begin{array}{c}\text { Mean } \\
\text { Square }\end{array}$ & F & Sig. \\
\hline 1 Regression & 187.933 & 1 & 187.933 & 24.366 & $0.000^{\mathrm{a}}$ \\
Residual & 701.873 & 91 & 7.713 & & \\
Total & 889.806 & 92 & & & \\
\hline
\end{tabular}

a. Predictors: (Constant), Existing Culture; b. Dependent Variable: Resistance.

While the adjusted R-square is $0.203,20.3$ per cent of variations in the dependent variable (Resistance) can be explained by the independent variable, which is existing culture.

Based on the regression model, as the probability of T-statistic for the existing culture is 0.000 , which is less than 0.05 , and it can be concluded that there is a significant positive relationship between existing culture and employee resistance.

TABLE VI

Coefficiency between Existing Culture and Employee Resistance.

Coefficients $^{\mathrm{a}}$

\begin{tabular}{|c|c|c|c|c|c|}
\hline \multirow{2}{*}{ Model } & \multicolumn{2}{|c|}{$\begin{array}{c}\text { Unstandardized } \\
\text { Coefficients }\end{array}$} & $\begin{array}{c}\text { Standardized } \\
\text { Coefficients }\end{array}$ & \multicolumn{2}{|c|}{} \\
\cline { 2 - 6 } & $\mathrm{B}$ & $\begin{array}{c}\text { Std. } \\
\text { Error }\end{array}$ & Beta & $\mathrm{t}$ & Sig. \\
\hline 1 (Constant) & 3.285 & 1.840 & & 1.785 & 0.078 \\
Existing & 0.239 & 0.048 & 0.460 & 4.936 & 0.000 \\
Culture & & & & & \\
\hline
\end{tabular}

a. Dependent Variable: Resistance.

The following tables show the summary model, one-way ANOVA, and coefficiency tables for the resistance, complexity, relative advantage, and confidence variables.

TABLE VII

Model Summary for Resistance, Complexity, Relative Advantage, Model Summary.

\begin{tabular}{|c|c|c|c|c|}
\hline Model & R & R Square & $\begin{array}{c}\text { Adjusted R } \\
\text { Square }\end{array}$ & $\begin{array}{c}\text { Std. Error of } \\
\text { the Estimate }\end{array}$ \\
\hline 1 & $0.735 \mathrm{a}^{\mathrm{a}}$ & 0.541 & 0.525 & 3.84280 \\
\hline
\end{tabular}

a. Predictors: (Constant), Resistance, Complexity, Relative Advantage, Confident.

The probability of F-statistic is 0.000 , which is less than 0.05 (significance level). Therefore, this model is considered significant.

TABLE VIII

One Way ANOV for Resistance, Complexity, Relative Advantage, Confident and E-commerce Adoption ANOVA ${ }^{\text {b }}$

\begin{tabular}{|c|c|c|c|c|c|}
\hline Model & $\begin{array}{c}\text { Sum of } \\
\text { Squares }\end{array}$ & df & $\begin{array}{c}\text { Mean } \\
\text { Square }\end{array}$ & F & Sig. \\
\hline 1 Regression & $1,997.770$ & 4 & 499.443 & 33.821 & $0.000^{\mathrm{a}}$ \\
Residual & $1,698.222$ & 115 & 14.767 & & \\
Total & $3,695.992$ & 119 & & & \\
\hline
\end{tabular}

a. Predictors: (Constant), Resistance, Complexity, Relative Advantage, Confidence; b. Dependent Variable: e-Commerce Adoption. 
While adjusted $\mathrm{R}$-square is $0.525,52.5$ per cent of variations in the dependent variable (Confidence of managers) can be explained by these four independent variables, namely, Relative Advantage, Complexity, Confidence and Resistance.

TABLE IX

Coefficiency between Confident, Complexity, Relative Advantage, Resistance and E-commerce Adoption.

Coefficients $^{\mathrm{a}}$

\begin{tabular}{|c|c|c|c|c|c|}
\hline \multirow{2}{*}{ Model } & \multicolumn{2}{|c|}{$\begin{array}{c}\text { Unstandardized } \\
\text { Coefficients }\end{array}$} & $\begin{array}{c}\text { Standardized } \\
\text { Coefficients }\end{array}$ & \multicolumn{2}{|c|}{} \\
\cline { 2 - 6 } & $\mathrm{B}$ & $\begin{array}{c}\text { Std. } \\
\text { Error }\end{array}$ & Beta & $\mathrm{t}$ & Sig. \\
\hline 1 (Constant) & 9.546 & 1.899 & & 5.026 & 0.000 \\
Relative & 0.382 & 0.139 & 0.296 & 2.750 & 0.007 \\
Advantage & 0.042 & 0.208 & 0.016 & 0.204 & 0.839 \\
\hline Complexity & 0.706 & 0.192 & 0.417 & 3.675 & 0.000 \\
\hline Confidence & 0.161 & 0.123 & 0.097 & 1.313 & 0.192 \\
\hline Resistance & & & & & \\
\hline
\end{tabular}

a. Dependent Variable: e-Commerce Adoption.

Based on the regression model, the probability of T-statistic for Relative Advantage is 0.007, which is less than 0.05 (significance level), and the coefficient of Relative Advantage in the regression model is 0.382 , which is positive. Therefore, it can be concluded that there is a significant positive relationship between Relative Advantage and the adoption of e-commerce. Based on the regression model, the probability of T-statistic for Complexity is 0.839 , which is not less than 0.05 (significance level), so there is no significant relationship between Complexity and the adoption of e-commerce.

Based on the regression model, as the probability of T-statistic for Confidence is 0.000 , which is less than 0.05 (significance level), and the coefficient of Confidence in the regression model is 0.706 , which is positive, it can be concluded that there is a significant positive relationship between Confidence and the adoption of e-commerce.

The results also show that the variables Trialability and Observability are positively correlated with the confidence level of the SME's management. On the other hand, the level of confidence in the management of SMEs has a positive influence on the adoption of e-commerce. Managements with high level of confidence have higher propensities to adopt e-commerce into the company, and vice versa.

Based on the regression model, as the probability of T-statistic for Resistance is 0.192 , which is not less than 0.05 (significance level), it can be concluded that there is no significant relationship between Resistance and the adoption of e-commerce. Based on the compatibility model, the existing culture of e-commerce adoption in SMEs can weaken an employee's resistance towards the adoption of e-commerce. This means that there is a positive relationship between the existing culture and the resistance of employees; therefore, employees with shifted culture demonstrated increased resistance, but there is no relationship between the resistance of employee and the adoption of e-commerce.

\section{CONCLUSIONS}

The result of the study shows that according to relative advantage, Malaysian SMEs are willing to adopt e-commerce due to its many advantages. Relative advantages influence the adoption of e-commerce, and this research shows that it increases the adoption of e-commerce among Malaysian SMEs. This result supports the results of the research by Chong and Pervan (2007), which also shows that the relative advantage is strongly related to the adoption of e-commerce among SMEs. Based on a study by Neale et al. (2006), SMEs that have adopted e-commerce can gain strategic advantages such as internal and external process integration, close relationships with customers and other business owners, influence market growth to earn external resources, and increase the expertise for growth and development of business.

Another objective of this study is to determine whether the variables of Trialability and 
Observability, via the adoption of e-commerce, could increase the level of confidence of business managers in order for them to continue with the adoption process. The result of the survey supports that the two factors from Rogers' model (Trialability and Observability) does influence the confidence level of managers. This happens when the management understands the perceived benefits of e-commerce, and trusts the implementation and adoption of e-commerce in their respective companies. In other words, when managers get a hold of more information, and are more familiar with the benefits of the adoption e-commerce, their confidence level will inevitably rise. A study by Pearson and Grandon (2005) discovered that the lack of security and reliability regarding e-commerce is significant barrier to the adoption of e-commerce. Also, the lack of knowledge regarding the advantages of e-commerce forms an important barrier that needs to be circumvented in the process of adopting e-commerce into business. In other words, the more information that the management possesses on e-commerce, the higher their level of confidence will be with regards to it.

The third objective of the study is to investigate whether the compatibility of the adoption of e-commerce process with the existing culture of SMEs is capable of decreasing the level of employee's resistance against the adoption of e-commerce. This research proves that the existing culture significantly influences employee's resistance to the adoption of e-commerce. Based on a research by Smollan and Sayers (2009), any organizational changes is fraught with challenges, due to the fact that change is sometimes intangible, and employees observe changes via behaviour, speech, morale, and organizational culture. Therefore, with the adoption of e-commerce, employees are facing several changes from business methods to organizational culture, and this can effect the adoption of current and future technologies within the companies. However, the resistance of employees negatively influences the adoption of e-commerce.

Finally, the last research objective is to investigate whether complexity reduces the adoption of e-commerce among Malaysian SMEs. This research shows that there is no relationship between complexity and e-commerce adoption. Based on the definition of Rogers' model, complexity has a negative relationship with the adoption of e-commerce. The result shows that there is no significance relationship between this factor and the adoption of e-commerce. Vidal et al. (2010) explained that the owners and managers of SMEs have an important role in encouraging the growth of innovation because they are familiar with the organizational system and the characteristics of SMEs. Managers must realize that they can have a positive influence on the adoption of technology by training their employees, and also trust technologies advantages. In conclusion, this study shows that the increase in the adoption of e-commerce by SMEs in Malaysia is significantly related to the management team, instead of the employees.

\section{RESUMO}

O atual clima de negócios necessita de competições que são muitas vezes duras e imprevisíveis. Todas as organizações, a despeito do tamanho ou da amplitude de operação, estão enfrentando sérios desafios competitivos. A fim de lidar com esse fenômeno, os gestores estão se voltando para o comércio eletrônico (e-comércio) em suas organizações. Este estudo busca explorar e explicar as diferentes dimensões envolvendo a adoção do e-comércio entre pequenas e médias empresas, com base em Cinco Fatores de Difusão do Modelo de Inovação criado por Rogers. Entretanto, neste estudo, empregamos métodos de survey. Um questionário foi distribuído por e-mail para 1.200 gerentes e empregados em fábricas e empreendimentos agrícolas, com uma taxa de resposta de $10 \%$. Os resultados obtidos indicam sem dúvida que a vantagem relativa influencia na adoção do e-comércio. Possibilidades de testes e de 
acompanhamento são fatores que afetam o nível de confiança por parte da administração o que, por sua vez, influencia a adoção do e-comércio. Ao mesmo tempo, a cultura vigente numa empresa afeta a resistência dos empregados a qual, por seu turno, afeta negativamente a adoção do e-comércio, ao passo que a complexidade não influencia significativamente a adoção do e-comércio.

Palavras-chave: adoção do e-comércio, PMEs, Modelo Rogers, difusão da inovação, e-negócio.

\section{REFERENCES}

Al-Somali SA, Gholami R and Clegg B. 2011. An Investigation into the Adoption of Electronic Commerce among Saudi Arabian SMEs. Journal of Electronic Commerce in Organizations 9(2): 41-65.

AL SUKKAR A AND HASAN H. 2005. Toward a model for the acceptance of internet banking in developing countries. Information Technology for Development 11(4): 381-398.

AZAM MS AND QuAdDDUS M. 2009a. Adoption of b2b e-commerce by the SMEs in Bangladesh: an empirical analysis. In Proceedings of Asian Business Research Conference, Dhaka.

AZAM MS AND QUADDUS M. 2009b. Adoption of e-commerce by the SMEs in Bangladesh: the effects of innovation characteristics and perceived risk. In Proceedings of the Australian and New Zealand Marketing Academy Conference, p. 1-9.

CHEN S. 2004. Adoption of electronic commerce by SMEs of Taiwan. Electronic Commerce Studies 2(1): 19-34.

Chong S AND Pervan G. 2007. Factors Influencing the Extent of Deployment of Electronic Commerce for Smalland Medium Sized Enterprises. Journal of Electronic Commerce in Organizations 5(1): 1-29.

DANIEL EM AND GRIMShaw DJ. 2002. An exploratory comparison of electronic commerce adoption in large and small enterprises. Journal of Information Technology 17(3): 133-147.

GRANDON EE AND PeARSON JM. 2004. Electronic commerce adoption: an empirical study of small and medium US Business. Information and management 42: 197-216.

Hunatti Z, Masa'Deh R, Mansour M and Al-Nawafleh A. 2009. Electronic commerce adoption barriers in small and medium-sized enterprises (SMEs) in developing countries: the case of Libya. IBIMA Business Review 2: 37-45.

Hussin H, Nor RM and Suhaimi MA. 2008. Perceived Attributes of E-Commerce and the Adoption Decision: The Case of Malaysian SMEs. Journal Teknologi Maklumat \& Multimedia 5(2008): 107-125.

JON K, LAI TL, HUI CK, DENNIS NCH AND MENG TS. 2001. Electronic commerce adoption by SMEs in Singapore. In System Sciences, 2001. Proceedings of the $34^{\text {th }}$ Annual Hawaii International Conference on IEEE, $10 \mathrm{p}$.
KARAKAYA F AND SHEA T. 2008. Underlying Motivations for Establishing E-Commerce Business and Their Relationship to E-Commerce Success. Journal of Internet Commerce 7(2): 153-179.

Kendall KE, Kendall JE AND KaH MM. 2006. Formulating information and communication technology (ICT) policy through discourse: how internet discussions shape policies on ICTs for developing countries. Information Technology for Development 12(1): 25-43.

LEE JW. 2002. Adoption of Information Technology in Small Business: Testing Drivers of Adoption for Entrepreneurs. Entrue Journal of Information Technology 1(1): 21-36.

MACGREGOR RC AND VRAZALIC L. 2007. E-commerce in regional small to medium enterprises. Igi Global.

MASWERA T, DAWSON R AND EDWARDS J. 2008. E-commerce adoption of travel and tourism organisations in South Africa, Kenya, Zimbabwe and Uganda. Telematics and Informatics 25(3): 187-200.

MIGIRO SO. 2006. Diffusion of ICTs and E-commerce adoption in manufacturing SMEs in Kenya. South African Journal of Library and Information Science 72(1): 35.

Nasco SA, Toledo EG AND Mykytyn PP. 2008. Predicting electronic commerce adoption in Chilean SMEs. Journal of Business Research 61(6): 697-705.

Neale J, Murphy J AND SCharl A. 2006. Comparing the Diffusion of Online Service Recovery in Small and Large Organizations. Journal of Marketing Communications 12(3): 165-181.

OLIVEIRA T AND MARTINS MF. 2010. Understanding e-business adoption across industries in European countries. Industrial Management \& Data Systems 110(9): 1337-1354.

Pearson JM AND GRANDON EE. 2005. An empirical study of factors that influence e-commerce adoption/non-adoption in small and medium sized businesses. Journal of Internet Commerce 4(4): 1-21.

PoOn S And Swatman P. 1997. The Internet for small businesses: An enabling infrastructure. In Fifth Internet Society Conference, p. 221-231.

POORANGI MM AND KHIN D. 2013. Strategic Alliance on Malaysia SMEs to compete globally. Endogenous and exogenous prospective. Actual Problem of Economics 3(141): 407-415.

ROGERS EM. 1995. Diffusion of Innovations, $4^{\text {th }}$ ed., New York: Free Press.

SAdowski BM, Maitland C AND VAN Dongen J. 2002. Strategic use of the internet by small-and medium-sized companies: an exploratory study. Information Economics and Policy 14(1): 75-93.

SEKARAN U. 2006. Research methods for business: A skill building approach. New York: John Wiley \& Sons, Inc.

SMOLlan K AND SAYers JG. 2009. Organizational Culture, Change and Emotions: A Qualitative Study. Auckland University of Technology, Auckland, New Zealand, Massey University, Albany. New Zealand Journal of Change Management 9(4): 435-457. 
STREET CT AND MEISTER DB. 2004. Small business growth and internal transparency: The role of information systems. MIS Quarterly 28(3): 473-506.

STYLIANOU AC, ROBBINS SS AND JACKSON P. 2003. Perceptions and attitudes about e-commerce development in China: an exploratory study. Journal of Global Information Management 11(2): 31-47.

TAN KS AND EZE UC. 2008. An Empirical Study of InternetBased ICT Adoption among Malaysian SMEs. Communications of the IBIMA 1(1): 1-12.
VidAl NG, Bull GQ AND KozAK RA. 2010. Diffusion of Corporate Responsibility Practices to Companies: The Experience of the Forest Sector. Journal of Business Ethics 94(4): 553-567.

WRESCH W. 2003. Initial e-commerce efforts in nine least developed countries: A review of national infrastructure, business approaches, and product selection. Journal of Global Information Management 11(2): 67-78. 